\title{
Evaluation and selection of promising soybean lines in diverse environments
}

\author{
M. A. Malek, F. I. Monshi ${ }^{1}$, L. Rahman ${ }^{2}$ and M. A. Hakim ${ }^{3}$ \\ Plant Breeding Division, Bangladesh Institute of Nuclear Agriculture (BINA), BAU Campus, Mymensingh-2202, \\ Bangladesh, ${ }^{1}$ Department of Genetics and Plant Breeding, Sylhet Agricultural University, Sylhet, ${ }^{2}$ Department of \\ Genetics and Plant Breeding, Bangladesh Agricultural University, Mymensingh, Bangladesh and ${ }^{3}$ Department \\ Agricultural Chemistry, Hajee Mohammad Danesh Science and Technology University, Dinajpur, Bangladesh
}

\begin{abstract}
An experiment was conducted to evaluate the performance of eight selected soybean lines along with two check varieties in respect of maturity period, seed yield and yield contributing characters at five different locations during rabi season of 2007. Except number of seeds per pod, other yield contributing characters, seed yield and maturity period showed significant variations both in individual location and combined over locations. Among the lines and check varieties BAU-S/64 produced the highest number of branches per plant (4.7) while the check variety Sohag produced the lowest (2.8). Bangladesh soybean-4 produced the highest number of pods per plant (61). The seed yield of BAU-S/69 was the highest $(2920 \mathrm{~kg} / \mathrm{ha})$ followed by BAU-S/64 $(2721 \mathrm{~kg} / \mathrm{ha})$ while BAU-S/5 produced the lowest seed yield $(2049 \mathrm{~kg} / \mathrm{ha})$. Among the five locations, the highest mean seed yield of $3167 \mathrm{~kg} / \mathrm{ha}$ was produced at Chandpur followed by Mymensingh (2790 kg/ha) and Noakhali (2538 kg/ha). The lowest seed yield was recorded at Ishurdi (1363 kg/ha).
\end{abstract}

Keywords: Soybean, Performance, Promising lines, Environments

\section{Introduction}

Soybean (Glycine $\max$ (L.) Merr.) is a leguminous crop and has a high value in agriculture as a good source of protein and vegetable oil. It also improves soil fertility through fixing nitrogen. In Bangladesh, soybean is mostly used as poultry feed and for making nutritious food dishes and confectionary items such as soyadal, soyakhechuri, soyabread, soyamilk and so on (Mondal and Wahhab, 2001; Rahman, 2003). Soybean can also play a vital role in balancing the protein deficiency of our diet. Soybean has high protein, which is 1.5-2.0 times than other pulses, 4 times than egg and wheat, 6 times than rice grain and 12 times than milk. Soybean contains 3\% lesithine, which is helpful for brain development. It is also enriched in calcium, phosphorus, Vitamin A, B, C and D (Rahman, 1982).

Due to the rice based cropping patterns, the areas under oilseeds, pulses and some other crops has been declining since 1970. At present, the domestic oilseed production is only 0.63 million tons, which gives only 0.20 million tons of edible oil and can meet only $25-30 \%$ of our requirement (Hossain and Rahman, 2008). To fulfill the requirement, Bangladesh is to import 1.20 million tons of edible oil annually at a cost of nearly Tk. 40 billions. There is a possibility of producing 1.6-1.8 million tons of soybean from 0.7 million hectares of char land and from other seasonal fellow land in Bangladesh.

There is a significant variation in yield and yield contributing characters and other agronomic characteristics of soybean genotypes. These variations have been found to increase or decrease when grown under different climatic and soil conditions even within limited latitude and under different climatic conditions influenced by different latitudes (Whigham, 1975). Genetic factors alone cannot control these variations. Sources of seeds are also a cause for variations (Hung and Shanmugasundaram, 1979) which complicated the entire issue of genotypes expressivity, but it does not happen always (Rahman et al., 1977). Development of high yielding variety requires information on variation among the breeding materials for yield and yield contributing characters. Therefore, the importance of evaluating advanced soybean lines at different agro-ecological conditions and screen out the good ones beyond descriptioni. So, the present experiment has been undertaken to evaluate the performance of eight selected promising soybean lines as compared to two check varieties in respect of maturity period, seed yield and yield contributing characters at five different locations. 


\section{Materials and Methods}

Eight promising soybean lines namely BAU-S/5, BAU-S/21, BAU-S/54, BAU-S/64, BAU-S/69, BAU-S/70, BAU-S/80 and BAU-S/83 along with two check varieties Sohag and Bangladesh soybean-4 (BDS-4) were collected from the Department of Genetics and Plant Breeding, Bangladesh Agricultural University (BAU), Mymensingh. These materials were put into trial at Bangladesh Institute of Nuclear Agriculture (BINA) hqs. farm, Mymensingh, BINA sub-station farms at Ishurdi and Magura, and at Haimchar upazila of Chandpur and sadar upazila of Noakhali districts during rabi season of 2007-'08. The trial was laid out in a randomized complete block design with three replications. Spacing was $30 \mathrm{~cm}$ between rows and 5-7 $\mathrm{cm}$ between plants in a row. Unit plot size was $19.5 \mathrm{~m}^{2}(5 \mathrm{~m} \times 3.9 \mathrm{~m})$. Sowing was done within the last week of December 2007 and first week of January 2008. Recommended production practices including application of fertilizers were followed to ensure normal plant growth and development. Data on various characters, such as plant height, number of primary branches and pods per plant, number of seeds per pod were taken from 10 randomly selected plants from each plot. Maturity period was counted when stem and pod of each plot turned into yellowish brown colour and almost all the leaves were shed in each plot. Seed yield of each plot was recorded and then converted into $\mathrm{kg} / \mathrm{ha}$. Appropriate statistical analyses were performed with the plot mean data of each character. Mean differences of different traits were tested by Duncan's Multiple Range Test (Gomez and Gomez, 1984).

\section{Results and Discussion}

Mean values for different characters of five individual locations and combined over locations of the trial are presented in Table 1. Except number of seeds per pod all other characters showed significant variations both in individual location and combined over locations.

Four lines i. e., BAU-S/54, BAU-S/64, BAU-S/69 and BAU-S/83 produced significantly taller plants than the other four lines and the check varieties, which showed similarity with the findings of Chandankar et al. (2002). BAU-S/64 produced the highest number of branches (6.1) in Chandpur while the lowest was found in the control variety Sohag (2.2) at Magura. Combined analysis over five locations showed that BAU-S/64 and BAU-S/69 produced higher number of branches per plant i. e., 4.7 and 4.1, respectively while the control variety Sohag produced only 2.8 branches per plant. Such variation was also observed by Saka et al. (1996).

Number of pods per plant, the important yield contributing character in legume, was the highest in BDS-4 (74) at Mymensingh and the lowest in BAU-S/21 (28) at Ishurdi. Combined means over locations showed that BDS-4 produced the highest number pods per plant (61) followed by BAU-S/64 and BAU-S/69 (51) while the lowest number in BAU-S/83 (38). These variations are in agreement with the findings of Raut et al. (2001). Number of seeds per pod, the another important yield component, showed insignificant difference among the lines in all the individual location except at Ishurdi. At Ishurdi, BAU-S/69, BAU-S/70 and BAU-S/80 produced the highest number of 2.9 seeds per pod while the lowest number was in BAU$\mathrm{S} / 54(2.3)$.

BDS-4 took the shortest maturity period (99 days) at Noakhali while the highest of 149 days was recorded in BAU-S/69 at Ishurdi. Combined means over locations showed that BDS-4 had the shortest maturity period (108 days) followed by BAU-S/21 and BAU-S/80 (109 days) while BAU-S/5 needed the longest maturity period of 128 days. Such variations in maturity are in agreement with the findings of Danee et al. (2002).

BAU-S/69 produced the highest seed yield of $4144 \mathrm{~kg} / \mathrm{ha}$ at Mymensingh while BAU-S/70 produced the lowest seed yield $(1040 \mathrm{~kg} / \mathrm{ha})$ at Ishurdi. Combined means over locations showed that BAU-S/69 produced the highest seed yield of $2920 \mathrm{~kg} / \mathrm{ha}$ followed by BAU-S/64 $(2721 \mathrm{~kg} / \mathrm{ha})$. BAU-S/21, BAU-S/80 and BDS-4 produced statistically insignificant seed yield with each other i. e., $2485 \mathrm{~kg} / \mathrm{ha}, 2523 \mathrm{~kg} / \mathrm{ha}$ and $2552 \mathrm{~kg} / \mathrm{ha}$, respectively. These results are in agreement with the results of Saka et al. (1996) and Rahman et al. (1996). 
Table 1. Mean performance of the soybean lines in individual location and combined over locations for different characters

\begin{tabular}{|c|c|c|c|c|c|c|}
\hline $\begin{array}{c}\text { Advanced } \\
\text { lines/varieties/ } \\
\text { Locations }\end{array}$ & $\begin{array}{l}\text { Plant height } \\
\text { (cm) }\end{array}$ & $\begin{array}{l}\text { No. of branches/ } \\
\text { plant }\end{array}$ & $\begin{array}{c}\text { No. of } \\
\text { pods/plant }\end{array}$ & $\begin{array}{c}\text { No. of } \\
\text { seeds/pod }\end{array}$ & $\begin{array}{l}\text { Days to } \\
\text { maturity }\end{array}$ & $\begin{array}{c}\text { Seed yield } \\
(\mathrm{kg} / \mathrm{ha})\end{array}$ \\
\hline \multicolumn{7}{|l|}{ Isihurd } \\
\hline BAU-S/5 & $74 c$ & $3.2 \mathrm{abc}$ & $45 a b$ & $2.7 a b$ & $147 b$ & 1150ef \\
\hline BAU-S/21 & 62def & $2.5 \mathrm{~cd}$ & $28 d$ & $2.6 a b$ & $120 \mathrm{e}$ & 1483b \\
\hline BAU-S/54 & $77 \mathrm{bc}$ & $2.7 \mathrm{bcd}$ & $45 a b$ & $2.3 b$ & $140 c$ & $1283 \mathrm{~cd}$ \\
\hline BAU-S/64 & $87 a b$ & $3.7 \mathrm{a}$ & $42 a b c$ & $2.6 a b$ & $147 \mathrm{~b}$ & 1250cde \\
\hline BAU-S/69 & $76 c$ & 3.4ab & $30 d$ & $2.9 a$ & $149 a$ & $1500 \mathrm{~b}$ \\
\hline BAU-S/70 & $73 \mathrm{~cd}$ & 3.1abcd & $32 \mathrm{~cd}$ & $2.9 a$ & $120 \mathrm{e}$ & $1040 f$ \\
\hline BAU-S/80 & $53 f$ & $2.8 \mathrm{bcd}$ & $44 a b c$ & $2.9 a$ & $118 f$ & $1650 a$ \\
\hline BAU-S/83 & $92 a$ & $2.7 \mathrm{bcd}$ & 34bcd & $2.5 \mathrm{~b}$ & $147 \mathrm{~b}$ & 1200de \\
\hline Sohag* & $58 \mathrm{ef}$ & $2.8 \mathrm{bcd}$ & $34 \mathrm{bcd}$ & $2.7 a b$ & $124 d$ & $1333 c$ \\
\hline BDS-4* & $67 \mathrm{cde}$ & $2.3 d$ & $48 a$ & $2.8 \mathrm{a}$ & $114 \mathrm{~g}$ & $1737 a$ \\
\hline \multicolumn{7}{|l|}{ Magura } \\
\hline BAU-S/5 & $72 \mathrm{~cd}$ & $3.7 \mathrm{bc}$ & $45 a b$ & 2.8 & $121 a$ & $1950 f$ \\
\hline BAU-S/21 & $64 d$ & $2.6 \mathrm{c}$ & $50 a b$ & 2.6 & $109 \mathrm{e}$ & $2530 c$ \\
\hline BAU-S/54 & $97 \mathrm{~b}$ & $2.9 a b$ & $48 a b$ & 2.4 & $115 \mathrm{c}$ & $2109 e$ \\
\hline BAU-S/64 & $99 b$ & $5.5 a$ & $52 a b$ & 2.7 & $119 b$ & $2450 \mathrm{~cd}$ \\
\hline BAU-S/69 & $105 b$ & $4.8 \mathrm{ab}$ & $53 a b$ & 2.6 & $116 c$ & $2689 b$ \\
\hline BAU-S/70 & $81 \mathrm{c}$ & $2.3 \mathrm{c}$ & $55 a b$ & 2.6 & $106 f$ & $2767 a b$ \\
\hline BAU-S/80 & $59 d$ & $2.8 \mathrm{c}$ & $56 a b$ & 2.6 & $107 f$ & $2856 a$ \\
\hline BAU-S/83 & $132 a$ & $5.6 a$ & $40 \mathrm{~b}$ & 2.6 & $112 d$ & 1995ef \\
\hline Sohag* & $69 \mathrm{~cd}$ & $2.2 \mathrm{C}$ & $50 a b$ & 2.6 & $109 \mathrm{e}$ & $2119 e$ \\
\hline BDS-4* & $79 c$ & $4.4 a b$ & $61 a$ & 2.8 & $106 f$ & $2378 d$ \\
\hline \multicolumn{7}{|l|}{ Noakhali } \\
\hline BAU-S/5 & 57 ef & $3.7 \mathrm{~b}$ & $38 b$ & 2.7 & $117 a$ & $1896 \mathrm{e}$ \\
\hline BAU-S/21 & $52 \mathrm{fg}$ & 2.6de & $48 a b$ & 2.5 & 101de & $2606 \mathrm{~cd}$ \\
\hline BAU-S/54 & $77 a$ & $3.6 \mathrm{bc}$ & $42 b$ & 2.4 & $112 b$ & $2565 \mathrm{~cd}$ \\
\hline BAU-S/64 & $69 \mathrm{bc}$ & $4.8 \mathrm{a}$ & $47 a b$ & 2.7 & $109 c$ & 2815ab \\
\hline BAU-S/69 & 71abc & $5.1 a$ & $48 a b$ & 2.8 & $108 \mathrm{c}$ & $2709 b c$ \\
\hline BAU-S/70 & $50 \mathrm{fg}$ & 3.0cde & $46 a b$ & 2.6 & $102 d$ & 2484d \\
\hline BAU-S/80 & $66 \mathrm{~cd}$ & $3.2 \mathrm{bcd}$ & $51 a b$ & 2.7 & $103 d$ & $2859 a b$ \\
\hline BAU-S/83 & $76 a b$ & $3.2 \mathrm{bcd}$ & $39 b$ & 2.4 & $111 b$ & $2074 \mathrm{e}$ \\
\hline Sohag* & $44 \mathrm{~g}$ & $2.5 \mathrm{e}$ & $50 a b$ & 2.6 & 100ef & $2917 a$ \\
\hline BDS-4* & 60de & $3.3 b c$ & $58 a$ & 2.8 & $99 f$ & $2459 d$ \\
\hline \multicolumn{7}{|l|}{ Chandpur } \\
\hline BAU-S/5 & $57 e$ & $3.5 b c$ & $40 \mathrm{~cd}$ & 2.5 & $118 a$ & $3100 \mathrm{~cd}$ \\
\hline BAU-S/21 & $49 f$ & $2.9 \mathrm{bc}$ & $50 \mathrm{bcd}$ & 2.5 & $103 e$ & $3270 b c$ \\
\hline BAU-S/54 & $77 \mathrm{~cd}$ & $4.2 \mathrm{~b}$ & 46bcd & 2.5 & 116b & $3120 \mathrm{~cd}$ \\
\hline BAU-S/64 & $83 b$ & $6.1 \mathrm{a}$ & $58 a b$ & 2.8 & $117 b$ & $3409 a b$ \\
\hline BAU-S/69 & $90 a$ & $3.6 \mathrm{bc}$ & $53 a b c$ & 2.6 & $117 b$ & $3555 a$ \\
\hline BAU-S/70 & $61 e$ & $2.4 \mathrm{C}$ & 46bcd & 2.6 & $106 d$ & 3017de \\
\hline BAU-S/80 & $46 f$ & $3.4 \mathrm{bc}$ & $50 \mathrm{bcd}$ & 2.6 & $104 \mathrm{e}$ & 3083cd \\
\hline BAU-S/83 & $81 b c$ & $4.0 \mathrm{bc}$ & $37 d$ & 2.4 & $112 \mathrm{c}$ & $2785 \mathrm{e}$ \\
\hline Sohag* & $49 f$ & $3.2 \mathrm{bc}$ & 48bcd & 2.5 & $104 \mathrm{e}$ & 3089cd \\
\hline BDS-4* & $75 d$ & $3.7 \mathrm{bc}$ & $65 a$ & 2.8 & $102 f$ & 3237bcd \\
\hline \multicolumn{7}{|l|}{ Mymensingh } \\
\hline $\mathrm{BAU}-\mathrm{S} / 5$ & $61 d$ & 2.9 & $37 \mathrm{bc}$ & 2.8 & $139 a$ & $2148 \mathrm{e}$ \\
\hline BAU-S/21 & $67 \mathrm{~cd}$ & 4.0 & $37 b c$ & 2.7 & $113 e$ & $2533 d$ \\
\hline BAU-S/54 & $94 a b$ & 3.8 & $60 a b$ & 2.8 & $141 a$ & $2617 d$ \\
\hline BAU-S/64 & $105 a$ & 3.5 & $58 a b c$ & 2.8 & $139 a$ & $3681 b$ \\
\hline BAU-S/69 & $108 a$ & 3.9 & $69 a$ & 2.9 & $139 a$ & $4144 a$ \\
\hline BAU-S/70 & $64 d$ & 3.7 & $43 b c$ & 2.6 & 117cd & $2632 d$ \\
\hline BAU-S/80 & $52 d$ & 3.3 & $36 b c$ & 2.5 & 115de & $2165 \mathrm{e}$ \\
\hline BAU-S/83 & $81 b c$ & 4.1 & $41 \mathrm{bc}$ & 2.9 & $126 b$ & $2571 d$ \\
\hline Sohag* & $63 d$ & 3.3 & $42 b c$ & 2.6 & $116 \mathrm{cde}$ & $2460 d$ \\
\hline BDS-4* & $95 a b$ & 4.4 & $74 a$ & 2.9 & $119 c$ & 2947c \\
\hline
\end{tabular}


Table 1. Contd.

\begin{tabular}{|c|c|c|c|c|c|c|}
\hline $\begin{array}{c}\text { Advanced } \\
\text { lines/varieties/ } \\
\text { Locations }\end{array}$ & $\begin{array}{l}\text { Plant height } \\
\text { (cm) }\end{array}$ & $\begin{array}{l}\text { No. of branches/ } \\
\text { plant }\end{array}$ & $\begin{array}{c}\text { No. of } \\
\text { pods/plant }\end{array}$ & $\begin{array}{c}\text { No. of } \\
\text { seeds/pod }\end{array}$ & $\begin{array}{l}\text { Days to } \\
\text { maturity }\end{array}$ & $\begin{array}{c}\text { Seed yield } \\
(\mathrm{kg} / \mathrm{ha})\end{array}$ \\
\hline \multicolumn{7}{|c|}{ Combined means over locations } \\
\hline BAU-S/5 & 64d & $3.4 \mathrm{cde}$ & $41 b$ & 2.7 & $128 \mathrm{a}$ & $2049 e$ \\
\hline BAU-S/21 & $59 e$ & $2.9 \mathrm{ef}$ & $43 \mathrm{~b}$ & 2.6 & $109 f$ & $2485 c$ \\
\hline BAU-S/54 & $84 b$ & $3.8 \mathrm{bc}$ & $48 a b$ & 2.5 & $125 c$ & $2337 d$ \\
\hline BAU-S/64 & $89 a b$ & $4.7 \mathrm{a}$ & $51 a b$ & 2.7 & $126 \mathrm{~b}$ & 2721b \\
\hline BAU-S/69 & $90 a$ & $4.1 \mathrm{~b}$ & $51 \mathrm{ab}$ & 2.8 & $126 \mathrm{~b}$ & $2920 a$ \\
\hline BAU-S/70 & $66 \mathrm{~d}$ & $2.9 \mathrm{ef}$ & $44 b$ & 2.7 & $110 \mathrm{e}$ & $2387 d$ \\
\hline BAU-S/80 & $55 \mathrm{e}$ & 3.1def & $47 \mathrm{~b}$ & 2.7 & $109 f$ & $2523 c$ \\
\hline BAU-S/83 & $92 a$ & $3.9 \mathrm{bc}$ & $38 \mathrm{~b}$ & 2.6 & $122 d$ & $2125 \mathrm{e}$ \\
\hline Sohag* & $57 \mathrm{e}$ & $2.8 f$ & $45 b$ & 2.6 & $111 \mathrm{e}$ & $2383 d$ \\
\hline BDS-4* & $75 c$ & $3.6 \mathrm{bcd}$ & $61 a$ & 2.8 & $108 g$ & $2552 c$ \\
\hline \multicolumn{7}{|l|}{ Location means } \\
\hline Ishurdi & $72 \mathrm{c}$ & $2.9 \mathrm{~b}$ & $38 b$ & 2.7 & $133 a$ & $1363 e$ \\
\hline Magura & $86 a$ & $3.9 a$ & $51 a$ & 2.6 & $112 \mathrm{c}$ & $2383 d$ \\
\hline Noakhali & $62 d$ & $3.5 a$ & $47 a$ & 2.6 & $106 \mathrm{e}$ & $2538 c$ \\
\hline Chandpur & $67 \mathrm{~cd}$ & $3.7 a$ & $49 a$ & 2.6 & $110 \mathrm{~d}$ & $3167 a$ \\
\hline Mymensingh & $79 \mathrm{~b}$ & $3.7 \mathrm{a}$ & $49 a$ & 2.7 & $126 \mathrm{~b}$ & $2790 b$ \\
\hline
\end{tabular}

* indicates check variety

Among the five locations, the highest mean seed yield of $3167 \mathrm{~kg} / \mathrm{ha}$ was produced at Chandpur followed by Mymensingh (2790 kg/ha) and Noakhali $(2538 \mathrm{~kg} / \mathrm{ha})$ with higher number of pods per plant. Ishurdi produced the lowest seed yield of $1363 \mathrm{~kg} / \mathrm{ha}$ with the highest maturity period of 133 days. Over the five locations, BAU-S/69 was the best performer followed by BAU-S/64 than the other lines and the check varieties regarding seed yield and yield contributing characters.

It could be concluded that more trials both at research field and farmer's field with wider agro-ecological regions would give more precise information to select the best one.

\section{References}

Chandankar, G.D., Datke, S.B., Rathod, D.R. and Khandare, N.O. 2002. Genetic Divergence studies in soybean. Annals plant Physiol. 16(1): 73-77.

Danee, M., Ahmad, M.R. and Grami, A. 2001. Cluster analysis of varieties. Iranian soybean collection and computing the relative discriminate functions. Iranian J. Agric. Sci. 32(2): 285-293.

Gomez, K.A. and Gomez. A.A. 1984. Statistical Procedure for Agricultural Research. $2^{\text {nd }}$ Edn. John Wiley and Sons, New York. 397411.

Hossain, M.D. and Rahman, M.A. 2008. Toil beez fasal utpadan briddhir somosya o tar somadhaner loskhe BARI udbhabita projukti somuha. In: Krishi Projukti Manual, M. Nazim Uddin, M. Ahmed, M.S. Alam, R.U. Shamim, S. Ullah and K.M. Salahuddin (eds), Bangladesh Agricultural research Institute, Joydebpur, Gazipur. pp. 39-43.

Hung, A.T. and Shanmugasundaram, S. 1979. Disruptive season and locational selection in soybean for Taiwan. World Soybean Res. Conf. II. 22-29, March, Raleigh, N. Carolina, U.S.A. p. 44.

Mondal, M.R.I. and Wahhab, M.A. 2001. Production Technology of Crops. Oil seed Research Center, Bangladesh Agril. Res. Inst. Joydebpur, Gazipur. pp. 1-10.

Rahman, L. 1982. Cultivation of soybean and its uses. City press, Dhaka. pp. 5-7.

Rahman, L. 2003. Studies on the development of varieties, production technology, food and fish feed uses of soybean in Bangladesh (BAU-USDA Soybean Project BG-ARS 107). P. 6.

Rahman, L., Quddus, M.A. and Shah-e-Alam, M. 1977. Annual Report No. 2, 1977-78. Brassica Breeding Project, Dept. Genetics and Plant Breed. Bangladesh Agril. Univ., Mymensingh.

Rahman, M.M., Kader, M. And Debi, B.R. 1996. Syudy of variation for yield and yield contributing characters and relation between them in soybean. Progress. Agric. 7(2): 61-64.

Raut, P.B., Kolte, N.N., Rathod, T.H., Shivankar, R.S. and Patli, V.N. 2001. Corelation and path co-efficient analysis of yield and its component in soybean. Annals plant Physiol. 15(1): 58-62.

Saka, K., Shipe, E.R. and Wallace, S.U. 1996. Relationships among plant characters in soybean with different seed size. Soybean Genetics Newsletter. 23: 225-229.

Whigham, D.K. 1975. International soybean variety experiment (ISVEX). First Report of Results. INTSOY Series No. 8. pp. $44-46$. 